\title{
MEMÓRIA SOCIAL E ESQUECIMENTO: O MUNICÍPIO, A ESCOLA E OS DIREITOS HUMANOS ${ }^{1}$
}

\author{
SOCIAL MEMORY AND FORGETTING: \\ THE CITY, THE SCHOOL AND HUMAN RIGHTS
}

DOI 10.20873/uft2179-3948.2021v12n1p49-71

\section{Ana Paula Poll ${ }^{2}$ Luiz Ricardo Candido Landin ${ }^{3}$}

"Num tempo, página infeliz da nossa história passagem desbotada na memória das nossas novas gerações..."

\begin{abstract}
Resumo: Este artigo tem por objetivo descrever e compreender a ausência de referências contemporâneas à história de violações de Direitos Humanos ocorridas no município de Barra Mansa, interior do estado do Rio de Janeiro, durante a ditadura militar brasileira (1964-1985). Para isso, utilizamos a perspectiva analítica de Pollak (1989) acerca do processo de enquadramento da memória e descrevemos o histórico de violações de Direitos Humanos na cidade. A pesquisa foi realizada a partir da coleta e análise de dados qualitativos obtidos com a aplicação de questionário em três escolas do município, abrangendo estudantes concluintes do terceiro ano do ensino médio, alunos do último módulo do Ensino de Jovens e Adultos (EJA). Aleatoriamente convidamos os respondentes do questionário aplicado para participarem de um grupo focal, ocasião em que estimulamos a discussão acerca dos Direitos Humanos e das violações ocorridas no antigo batalhão de Barra Mansa. Assim pudemos verificar que os egressos da rede pública de ensino de Barra Mansa/RJ desconhecem o passado de violações de Direitos Humanos ocorridos no município. Discutimos em consonância com os resultados obtidos o direito à memória e a necessidade de uma educação alicerçada nas diretrizes curriculares nacionais. Essas asseguram ao educando a compreensão acerca da importância do caráter plural da memória social e da relevância dos Direitos Humanos na formação do cidadão.
\end{abstract}

Palavras-chave: memória social; direitos humanos; educação.

Abstract: This paper aims to describe and understand the absence of contemporary references to the history of human rights violations that occurred in the municipality of Barra Mansa, in

\footnotetext{
1 Trabalho realizado no âmbito do Centro de Memória do Sul Fluminense Genival Luiz da Silva - CEMESF e financiados por bolsa de iniciação científica, ao qual agradecemos imensamente pelo apoio e suporte.

${ }^{2}$ Doutora em Ciências Humanas (Antropologia Cultural), pelo PPGSA do Instituto de Filosofia e Ciências Sociais da Universidade Federal do Rio de Janeiro. Professora Associada da Universidade Federal Fluminense. Docente do quadro permanente do Programa de Pós-Graduação em Políticas Públicas e Desenvolvimento/ Mestrado Profissional em Administração Pública e do Programa de Pós-Graduação em Tecnologia Ambiental. Email:anapaulapoll@yahoo.com.br

${ }^{3}$ Graduado em Administração Pública pela Universidade Federal Fluminense. Pesquisador e ex-bolsista do Centro de Memória do Sul Fluminense Genival Luiz da Silva.E-mail: lr_landim@id.uff.br.
} 
Rio de Janeiro, during the Brazilian military dictatorship (1964-1985). For this, we use the analytical perspective of Pollak (1989) about the process of framing memory and describe the history of human rights violations in the city. The research was carried out from the collection and analysis of qualitative data obtained with the application of a questionnaire in three schools in the city, covering students graduating from the third year of high school, students in the last module of Education for Young People and Adults. We randomly invited the respondents to the questionnaire applied to participate in a focus group, when we stimulated the discussion about Human Rights and the violations that occurred in the army building of Barra Mansa. Thus, we could verify that the graduates of the public school system in Barra Mansa/RJ aren't knowing of the past of human rights violations that occurred in this city. In line with the results obtained, we discuss the right to memory and the need for education based on national curriculum guidelines. These ensure that the student understands the importance of the plural character of social memory and the relevance of Human Rights in the formation of citizens.

Keywords: social memory; human rights; education.

\section{Introdução}

O município de Barra Mansa situa-se no interior do Rio de Janeiro na região sulfluminense, localizado a $133 \mathrm{~km}$ da capital, a cidade possui uma população estimada de 184.412 pessoas $^{4}$. Na região central do município encontra-se um palecete construído para abrigar a câmara de vereadores do município, conhecido como Palácio Barão de Guapi. A câmara funcionou neste imóvel até 2005. Com sua imponente arquitetura neoclássica, o prédio foi concluído em 1865 e por mais de um século abrigou o legislativo municipal. Atualmente ${ }^{5}$ funciona como biblioteca e dispõe de um enorme salão no piso superior. Esse espaço é utilizado para realizar celebrações, sediar eventos de entidades da sociedade civil organizada, e também é utilizado para algumas sessões solenes do Poder Legislativo. Um fato chama atenção no salão: suas paredes encontram-se revestidas por quadros de pessoas que foram relevantes para a história do município e do país. O que à primeira vista parece usual revela-se, em seguida, desconcertante. Pois, a maioria dessas personalidades retratadas na pinacoteca esteve diretamente ligada ao passado de violações de Direitos Humanos no município. A pinacoteca do Palácio Barão de Guapi apresenta aos visitantes, como figuras de destaque, os grandes proprietários de terra do período escravocrata e, igualmente, os chefes de Estado que governaram o país durante os períodos de supressão da ordem democrática ${ }^{6}$. Em visita ao local,

\footnotetext{
${ }^{4}$ IBGE Cidades, 2019

${ }^{5}$ Como está em obras desde 2018, o acesso ao espaço está interrompido.

${ }^{6}$ São personalidades ligadas à violações de Direitos Humanos e presentes nestes quadros: Custódio Ferreira Leite, o Barão de Aiuruoca - considerado um dos fundadores da cidade e grande produtor de café, utilizava mão de obra escrava e chegou a traficar escravos para a província de Minas Gerais - e os ditadores militares Humberto Castelo Branco, Arthur da Costa e Silva e Emílio Garrastazu Médici.
} 
num daqueles momentos em que a ausência torna-se evidência, nos damos conta que os presidentes eleitos após a redemocratização do Brasil não fazem parte desse acervo. Assim nos parece uma ausência essencialmente reveladora acerca da história que se pretende glorificar.

A violação de Direitos Humanos na cidade é um fato marcante de sua história, porém poucos moradores a conhecem. Durante a ditadura militar funcionou no município um "centro de tortura" que hoje em dia é popularmente conhecido como "Parque da Cidade", um local que já foi utilizado para exibição de shows, para hospedar trupes circenses e mais recentemente, tem abrigado o tiro de guerra, a guarda municipal, uma feira de negócios e diversas atividades culturais. Bem ao lado do que hoje é chamado de "Parque da Cidade", a cerca de 200 metros de onde as torturas aconteciam ${ }^{7}$, existe uma escola, e em um raio de até 1,5 km existem outras duas escolas. Essas três escolas caracterizam-se por serem de ensino médio, fases finais de estudo de muitos moradores no município. A proximidade das escolas com o antigo centro de tortura e o contato com ex-alunos do ensino médio de Barra Mansa na Universidade Federal Fluminense nos informava que o passado de violações de Direitos Humanos durante a ditadura civil-militar acabou se tornando o que foi chamado por Pollak (1989) de memória subterrânea, desconhecida por uma parcela significativa da população e latente entre as vítimas, sobreviventes e seus familiares. Deste modo, a hipótese de que as escolas do município não abordam a temática dos Direitos Humanos a partir das histórias de violações ocorridas na localidade, foi levantada. Neste caso, postulamos a ocorrência do enquadramento da memória (POLLAK, 1989) no município.

Para conduzir esse trabalho descrevemos brevemente o histórico de violações de Direitos Humanos na cidade e a perspectiva analítica utilizada por Pollak (1989) para conceituar o processo de enquadramento da memória. O objetivo deste artigo é descrever e compreender a ausência de referências contemporâneas à história de violações de Direitos Humanos ocorridas em Barra Mansa durante o regime de exceção brasileiro (1964-1985). A chave analítica para essa compreensão será a perspectiva do enquadramento da memória sobre os casos de torturas ocorridas nas dependências do antigo Batalhão de Infantaria Blindada ( $1^{\circ}$ BIB), situado no município de Barra Mansa. Os alunos do último ano do ensino médio das escolas do entorno do antigo $1^{\circ}$ BIB foram objeto desse estudo.

Foi utilizada a pesquisa qualitativa para a realização do estudo. Pois pretendeu-se compreender, em profundidade, o sentido atribuído por aqueles jovens ao espaço que abrigou

\footnotetext{
7 Síntese do Processo Criminal a que responde o Ten Cel Gladstone Pernasseti Teixeira, dados sobre os testemunhos da verdade e diligência da CV Rio.
} 
o antigo centro de torturas. Vale destacar que os dados buscados pela pesquisa qualitativa visam analisar a subjetividade do objeto de estudo, ou seja, a percepção dos concluintes do ensino médio quanto aos fatos ocorridos no município, a saber, graves violações de Direitos Humanos. Para além da percepção subjetiva analisada, realizou-se também um pequeno survey, aplicamos questionários com dez perguntas objetivas para os alunos. Esse questionário investigou a posição dos jovens frente aos seguintes temas: Direitos Humanos, memória, verdade e justiça no município. Como estratégia para aperfeiçoarmos essa compreensão foi realizado um grupo focal na escola mais próxima ao antigo batalhão.

O trabalho confirmou nossa hipótese inicial, a de que os egressos da rede de ensino municipal e estadual presentes na localidade desconhecem que Barra Mansa foi cenário de severas violações de Direitos Humanos durante o período da ditadura civil-militar.

\section{Memória oficial e enquadramento}

Maurice Halbwachs (1990), representante da escola sociológica francesa, apresenta uma análise da construção da memória em dois aspectos: de uma maneira individual, mais usualmente reconhecida, e de outra, a memória coletiva. Enfatizando essa última em sua análise, Halbwachs afirma que a forma mais acabada de uma memória é a do maior grupo a que ela pode pertencer, no caso a memória da nação, que também é conhecida como "memória oficial”. Assim, a 'memória oficial' engloba os fatos que são considerados mais importantes e que modificam a vida da nação. Uma perspectiva que invisibiliza a memória social de segmentos minorizados por diferentes processos históricos.

Michael Pollak (1989) aborda outro aspecto da construção da memória social. Para ele, a construção da memória coletiva se dará em um processo de negociação e conflitos entre as memórias individuais, privilegiando algumas memórias em detrimento de outras. Essas outras memórias ficarão no imaginário de quem as vivenciou, de maneira subterrânea em relação à sociedade envolvente. Assim, ele apresenta dois conceitos: a memória oficial, construída no processo de negociação, e tida como o ponto de referência de todos os membros da comunidade e a memória subterrânea, que é posta à margem no processo de construção da memória social. Assim sendo, o processo de enquadramento da memória é arbitrário, privilegiando algumas memórias que entram no bojo das 'memórias oficiais'. A relevância de sua perspectiva para o caso concreto que analisamos é que as memórias obliteradas, seja pela violência física ou simbólica, ganham destaque e tornam-se peça chave para compreensão de mudanças sociais relevantes. 
Pollak (1989) nos remete à importância da história oral para resgatar e trazer à tona as memórias subterrâneas dentro desse processo arbitrário e denotar o quão a margem da sociedade elas vivem. Apenas no momento que as vozes dessas minorias emergirem sua importância e a dos fatos narrados sob suas perspectivas virão à tona, começando a disputar um espaço em meio a memória oficial:

\begin{abstract}
Ao privilegiar a análise dos excluídos, dos marginalizados e das minorias, a história oral ressaltou a importância de memórias subterrâneas que, como parte integrante das culturas minoritárias e dominadas, se opõem à 'Memória oficial', no caso a memória nacional. [...] Por outro lado, essas memórias subterrâneas que prosseguem seu trabalho de subversão no silêncio e de maneira quase imperceptível afloram em momentos de crise em sobressaltos bruscos e exacerbados. A memória entra em disputa. (POLLAK, 1989, p.4)
\end{abstract}

São vários os caminhos de utilização da história oral para trazer à tona as memórias invisibilizadas. No caso analisado entendemos que a história oral consubstanciou políticas públicas com vistas à garantia de direitos difusos, como o direito à memória. É importante destacar que uma política pública "é uma diretriz elaborada para enfrentar um problema público" (SECCHI, 2014, p. 1). Neste caso, o silêncio acerca de violações ocorridas durante o regime de exceção passou a ser significado como 'problema público's ${ }^{8}$. Não só porque ocultava crimes de Estado, ou crimes praticados em nome dele, mas porque neglicenciava as memórias daqueles que resistiram à violência. Inviabilizando, assim, o acesso das novas gerações às memórias de uma parcela dos cidadãos brasileiros. Tratamos, assim, da Comissão Nacional da Verdade $^{9}$ como política pública e como garantidora do direito à memória, um direito difuso ${ }^{10}$ garantido em nossa Carta Constitucional.

Através do uso da história oral emergiram histórias guardadas por pessoas que vivenciaram experiências de graves violações, ou ainda, por seus parentes. Isso demonstra como a memória desprivilegiada de um certo indivíduo ou grupo pode ultrapassar a barreira do tempo sendo propagada no âmbito familiar. Essas narrativas contidas em pequenos círculos

\footnotetext{
${ }^{8}$ A temática só passou a ser abordado como um problema público após a vitória da presidenta Dilma Rousseff (PT), em 2010, que possibilitou a Comissão Nacional da Verdade. Rousseff foi presa política e torturada pela ditadura militar entre 1970 e 1972.

${ }^{9}$ A Comissão Nacional da Verdade foi criada pela Lei 12528/2011 e instituída em 16 de maio de 2012, tendo por finalidade apurar graves violações de Direitos Humanos ocorridas entre 18 de setembro de 1946 e 5 de outubro de 1988.

10 Segundo Zaneti Junior, "tem-se por direitos difusos (art. 81, § único, I, do CDC e art. $1^{\circ}$, I, do CM) aqueles transindividuais (metaindividuais, supraindividuais, pertencentes a vários indivíduos), de natureza indivisível (só podem ser considerados como um todo), e cujos titulares sejam pessoas indeterminadas (ou seja, indeterminabilidade dos sujeitos, não há individuação)", Assim sendo, por não se conseguir ter a definição certa de quem são todos os detentores do direito à memória, já que nem todos os casos de violações de Direitos Humanos no período da ditadura militar vieram a tona, podemos considera-la como um direito difuso..
} 
familiares nos remetem, portanto, a um passado diferente daquele assegurado pela memória oficial, conhecida por todos. Políticas públicas garantidoras de direitos difusos, como parece ter sido o caso das comissões da verdade, podem tornar-se "janelas de oportunidades políticas", trazendo à tona memórias subterrâneas.

Pollak (1989, p.9) atribui duas funções essenciais à memória: “manter a coesão interna e defender as fronteiras daquilo que um grupo tem em comum, em que se inclui o território (no caso de Estados)". Com isso, ressalta-se a possibilidade de ocorrência do enquadramento da memória. A memória é concebida a partir da sua função integradora para o grupo em comum, em geral uma maioria (mesmo que relativa) forjada a partir das relações de poder e conflito no interior da vida social. O enquadramento da memória forjará a memória oficial tendo como materiais o que é fornecido pela história, como monumentos arquitetônicos e históricos, personagens, datas e destinará ao silêncio outras vozes, personagens, episódios históricos, entre outros. Nesse trabalho, como em Pollak (1989), compreendemos a memória para além de sua função de reforçar as fronteiras sociais. As memórias, tomadas em sua pluralidade inerente à complexidade da via social, podem alterar essas fronteiras e, em meio aos conflitos e disputas que caracterizam o cenário social, podem fazer emergir uma história ressignificada. Essa história tornar-se-ia, então uma resultante das memórias e vozes silenciadas no passado. Afinal, como destacou Arendt (1988) a memória daqueles que foram submetidos ao silêncio imposto é fundamental tanto para a compreensão do presente quanto para pensarmos prospectivamente o futuro.

\section{Passado escravagista do município ${ }^{11}$}

A cidade de Barra Mansa tem sua origem no século XIX com o crescimento demográfico da região sul-fluminense como um todo, tendo sido elevada à categoria de vila em 1832 e se emancipado politicamente em 1833. Por ser uma cidade com grande produção cafeeira e rural nesse período, Barra Mansa concentrou grande quantidade de mão de obra escrava. "Em 1840 [...] Barra Mansa, cuja população somava então aproximadamente 12.100 habitantes, o percentual de cativos era de 56,36\%." (COUTO, 2016, p.33).

Durante aquele período a mão de obra escrava era algo típico no país. Era comum a mão de obra escrava ir para além das porteiras das fazendas e estarem no meio urbano também,

\footnotetext{
11 Entendemos que até o presente momento no texto tratar escravidão como violação de Direitos Humanos é visto como algo anacrônico, já que a noção de Direitos Humanos dá-se apenas com a elaboração da DUDH. Porém, nessa seção, destacamos a presença da mão de obra escrava como algo valorativo ao período abordado no município de Barra Mansa.
} 
sendo demonstrado como algo de valor para quem dela fosse detentora. Qualquer família poderia ter um escravo e usá-lo como um meio de se obter recursos financeiros, por vezes, única fonte de renda. Era até mesmo comum escravos libertos terem escravos. Isso demonstra o quão profundo, marcante e enraizado foi a escravidão na sociedade brasileira durante o período, sendo escravista em praticamente todos as esferas sociais, dos mais altos aos mais baixos extratos de renda. Com isso, a escravidão no Brasil tornou-se um valor, socialmente significativo (CARVALHO, 2002).

Toda pessoa com algum recurso possuía um ou mais escravos. O Estado, os funcionários públicos, as ordens religiosas, os padres, todos eram proprietários de escravos. Era tão grande a força da escravidão que os próprios libertos, uma vez livres, adquiriam escravos." (CARVALHO, 2002, p. 19-20)

Em Barra Mansa também podemos encontrar um entrelaçamento entre membros da política local e grandes proprietários de terra e mão de obra escrava durante o período imperial. Domiciano de Arruda, primeiro presidente da Câmara Municipal de Barra Mansa, era proprietário de uma grande fazenda que possuía 300 escravos. Custódio Ferreira Leite, o Barão de Aiuruoca, reverenciado como fundador do município, era um grande cafeicultor e traficante de escravos para Minas Gerais (MARTINS, 2008).

Em maio de 1888 foi promulgada no Brasil a lei que proibiu a mão de obra escrava no país, tendo abolido tardiamente a escravidão. Apenas sessenta anos depois da abolição tardia, em dezembro de 1948, foi promulgada a Declaração Universal dos Direitos Humanos, sendo o Brasil um dos países signatários e um dos primeiros a ratificar o documento. Essa Declaração traz, ao longo de seus 30 artigos, garantias às liberdades individuais e coletivas e à dignidade das pessoas, "sem distinção de qualquer espécie, seja de raça, cor, sexo, idioma, religião, opinião política ou de outra natureza, origem nacional ou social, riqueza, nascimento, ou qualquer outra condição.” (Art. 2, Declaração Universal Dos Direitos Humanos).

Mesmo passados 133 anos do fim da escravidão no país e com o advento da Declaração Universal dos Direitos Humanos, Barra Mansa ainda carrega atualmente marcas da memória escravagistas no município. Um exemplo é reificado pela pinacoteca do Palácio Barão de Guapi, que preserva a memória escravagista e autoritária da cidade, sem garantir espaço de representatividade aos dirigentes ou cidadãos vinculados à redemocratização do país ou a sua, ainda incipiente e claudicante, democracia. Embora possa parecer anacrônico abordar o tema dos Direitos Humanos relacionando-o ao período escravagista, compreendemos que a antiga câmara de vereadores de Barra Mansa, conhecida como Palácio Barão de Guapi, nos autoriza 
estabelecer, mesmo que de forma breve, relação entre um passado recente autoritário e um passado remoto escravagista. Assim como as cartas do passado parecem organizar as relações sociais no presente.

\section{Violação de Direitos Humanos durante a ditadura militar}

Para além das gravuras à óleo de barões escravagistas, dentro do palacete há também quadros dos três primeiros ditadores do governo militar (pós-golpe de 1964). Trata-se dos militares: Humberto Castelo Branco, Artur Costa e Silva e Emílio Garrastazu Médici. Essas imagens trazem à tona a memória desse passado sombrio, sem fazer menção ao fato de que no município casos de torturas aconteceram durante o regime militar.

Devido à presença da Companhia Siderúrgica Nacional - CSN, em Volta Redonda ${ }^{12}$, e as constantes manifestações operárias, sindicais e católicas contrárias à ditadura em vigor, funcionou no município de Barra Mansa um "centro de torturas". O local, na época, era conhecido como $1^{\circ}$ Batalhão de Infantaria Blindada - $1^{\circ}$ BIB. A instalação do $1^{\circ} \mathrm{BIB}$ deu-se ainda no ano de $1955^{13}$ (BEDÊ, 2015, p. 390) já devido à proximidade com a CSN, sendo a distância de um local ao outro de apenas 9,4 km. Uma forma de 'controle' da formação da classe operária emergente que ganharia mais atribuições com as repressões instauradas no pós1964.

Dentro do $1^{\circ}$ BIB, há um local chamado de "Arquivo", por ex-presos políticos. Construído em 1969, o local, que conta com um salão, duas celas surdas e sanitários, foi construído justamente com o intuito de isolar os presos políticos da ditadura, ainda mais por encontrar-se afastado cerca de 300 metros das instalações principais do batalhão e intercalado por ruas e prédios. Devido à localização e distância, todos os sons produzidos no interior do “arquivo" eram inaudíveis em seu exterior (Centro De Memória Do Sul Fluminense, 2019).

O local funcionou como palco de violações de Direitos Humanos até o ano de 1972 (BEDÊ, 2015), quando foi transformado em $22^{\circ}$ Batalhão de Infantaria Motorizada - $22^{\circ} \mathrm{BIMtz}$ devido aos graves escândalos de torturas e mortes, como o assassinato de quatro soldados nas

\footnotetext{
${ }^{12}$ A origem de Volta Redonda está diretamente ligada a cidade de Barra Mansa. Quando a CSN foi fundada, em 1941, o local onde hoje se encontram a Companhia e a cidade de Volta Redonda, pertenciam a Barra Mansa, sendo conhecidos como oitavo distrito. Anos mais tarde, em 1954, devido a autonomia econômica que o local se encontrava e vendo que a dependência do distrito para com o município sede era desvantajosa, o município atingiu sua emancipação (PMVR, 2020).

${ }^{13}$ Apesar da instalação do I ${ }^{\circ}$ BIB dar-se em 1955, o local foi construído nos anos 1930 com a construção do espaço conhecido como "Tulhas do Café". Lá sacas de café eram armazenadas e posteriormente queimadas durante do Governo Vargas. É valido relembrar que a cidade possui um passado ligado a produção de café e ao uso da mão de obra escrava para isso, como já dito acima.
} 
dependências do batalhão. Renomear o batalhão também parece ter sido uma estratégia para impor esquecimento aos fatos ocorridos no local.

O caso dos quatro soldados ocorreu entre os dias 31 de Dezembro de 1971 e 26 de janeiro de 1972. Nesse intervalo de quase um mês houve a prisão, a tortura e o assassinato dos jovens soldados: Geomar Ribeiro da Silva, Juarez Monção Virote, Roberto Vicente da Silva e Wanderley de Oliveira. Na época o alegado motivo da prisão, torturas e assassinato dos jovens, veiculado na mídia, teria sido o uso e tráfico de drogas nas dependências do $1^{\circ} \mathrm{BIB}$. Recurso comumente utilizado, inclusive na atualidade, para justificar a violação de direitos.

Geomar foi preso no dia 31 de dezembro. No dia 2 de janeiro, sua irmã Geralzélia conseguiu visitá-lo, onde o mesmo jurou que não havia usado drogas e que não confessaria algo que não fez (SERBIN, 2001). No dia 13 de janeiro, às 22h, a família foi chamada ao quartel a fim de receber o cadáver do filho, nesta ocasião foi constatado vários sinais de violência. Embora o seu corpo estivesse cheio de sinais de torturas, o laudo médico relacionou sua morte com problemas de coração, fígado e rins.

Roberto Vicente foi prestar serviço no dia 12 de janeiro no $\mathrm{I}^{\circ} \mathrm{BIB}$ e ficou detido para averiguação de suspeita de tráfico no local. No dia 14 quando sua mãe foi visitá-lo no quartel, ela foi informada da remoção do filho para o Hospital Central do Exército (HCE), no Rio. Ele faleceu no dia 24, tendo tido um último contato com uma irmã e uma tia. Nesta visita os familiares puderam ver que o soldado estava com curativos no crânio e estava com a parte abaixo da cintura toda enfaixada:

\footnotetext{
Minha filha, Ana Maria, trabalhava de empregada no Rio. Aí ela foi chamada do hospital, chegou lá e a única coisa que ele conseguiu falar com ela é que ele não fez nada, que ele e mais os dois que apanhou eram inocentes. E bateram nele até acabar: Chegou com a cabeça desse tamanho. Botaram a cabeça dele no torno. Ele estava muito deformado, segundo o que a minha filha falava estava muito deformado. Dos dois que estavam sendo torturados, me parece que meu filho, Juarez e Vanderlei, dia 12 , os dois não resistiram e morreram na hora. $\mathrm{O}$ meu filho ainda tava vivo. Ele morreu dia 25 lá no HCE no Rio (Depoente à Comissão Municipal da Verdade de Volta Redonda, 2015, p. 349)
}

Já Juarez Monção Virote e Wanderley de Oliveira tiveram um destino pior que os outros dois soldados. Wanderley foi detido, em casa, no dia 11 de janeiro de 1972 e Virote enquanto estava prestando serviço, no dia 12 de janeiro de 1972. Segundo a denúncia do procurador José Manes Leitão sobre o caso, ambos foram espancados durante todo o dia 12, tendo falecido no anoitecer daquele mesmo dia. Ambos foram assassinados pelo Capitão Niebus e sua equipe. A fim de despistar o assassinato, o Tenente Coronel Gladstone Pernasetti Teixeira autorizou que o telhado das dependências prisionais fosse danificado, simulando uma fuga dos soldados. 
Enquanto isso, notas eram emitidas nas rádios e jornais locais sobre dois soldados que haviam fugido do Batalhão, deixando os familiares aflitos sem notícias de seus filhos que já estavam mortos.

Destaca-se o fato de que este foi o único caso brasileiro de condenação de militares por prática de torturas e execução sumária ocorridos em dependências do exército entre 1964, início da Ditadura Militar e 1979, ano da promulgação da Lei da Anistia. Os responsáveis pelos crimes foram julgados e condenados em um Inquérito Policial Militar ${ }^{14}$. Os culpados pelo caso cumpriram por pouco tempo a pena inicialmente estabelecida, sendo elas posteriormente reduzidas em tribunais recursais.

Passadas algumas décadas, pouco são os moradores da cidade que sabem dessa e de outras histórias de torturas e mortes ocorridas nas dependências do antigo BIB. Nem mesmo pessoas com mais idade conhecem os detalhes do caso. Vê-se as memórias das vítimas, dos sobreviventes e de seus parentes silenciada. Assim, todo cidadão de Barra Mansa tem se tornado testemunha do esquecimento imposto às vitimas e sobreviventes de violações de Direitos Humanos. Apesar de parecer consensual nos círculos acadêmicos que fatos dessa gravidade devam ser rememorados para que não sejam repetidos.

\section{Democracia consensual}

Alguns anos depois do caso dos quatro soldados, no dia 28 de agosto de 1979, ainda durante a Ditadura Militar, o então ditador João Baptista Figueiredo promulgou a Lei 6.683, conhecida como Lei da Anistia. Essa lei representou um marco de transição entre a ditadura militar e o Estado de Direito, por supostamente superar o drama vivido pelo autoritarismo de Estado à época. Porém essa lei corroborou com o silenciamento de vários fatos de violações aos Direitos Humanos ocorridos até sua promulgação. A Lei anistiava não somente os presos políticos, em geral, pessoas que sofreram torturas praticadas por agentes do Estado e que precisaram exilar-se em outros países, mas também anistiava os generais, outros membros das forças armadas do país e do aparato repressivo que atuou em nome do Estado e foram responsáveis por torturar e assassinar. Dando origem assim, a uma democracia silenciada e consensual.

\footnotetext{
${ }^{14}$ Foram eles, Capitão Dálgio Miranda Niebus, com uma sentença de 84 anos por homicídio e perda de patente; Tenente-Coronel Gladstone Pernasetti Teixeira, que ordenou que mutilasse e escondesse os corpos, foi condenado a 7 anos de prisão; Tenente Miranda, tido como o elemento que mais torturou, recebeu pena de 77 anos de prisão; Sargentos Souza e Oliveira e Cabo Cruz receberam penas de 62 anos e o Sargento Guedes e o cabo Freitas Filho, penas de 58 anos.
} 
Para Edson Teles (2009, p. 3), essa democracia consensual "apaga, esquece, silencia a aparência, o erro na contagem do povo", fazendo com que toda a violação de Direitos Humanos ocorridos no período ditatorial no Brasil caia no esquecimento. Teles (2009) vai além e aborda o silêncio tanto por parte da vítima quanto pela sociedade e Estado:

\begin{abstract}
Parece haver dois tipos de silêncio no pós-ditadura brasileiro: há o silêncio das vítimas e dos sobreviventes da repressão que se calam pela própria incapacidade de dizer o indizível do horror vivido nas salas de tortura, pela ausência de uma dimensão pública para a narrativa; e, há o silêncio mais geral, de parte da sociedade brasileira indivíduos e instituições, do Estado e não-governamentais -, que se nega a falar ou ouvir o assunto, eximindo-se de qualquer responsabilidade coletiva que todo povo, governo e instituições têm com o coletivo e com sua história. (TELES, 2009, p. 7)
\end{abstract}

Esse silêncio praticado durante décadas pelo Estado após a promulgação da Lei da Anistia foi criado pelo que Teles (2009) chamou de "entulho autoritário", ou seja, trouxe ao campo da política a impossibilidade de se falar de casos de torturas no país, criando um âmbito de mudez social. Nesse âmbito, pouco era falado sobre o cenário político, criando um campo de disputa entre coletivos que buscavam por este debate nas relações políticas.

Quase uma década após a promulgação da Lei da Anistia, o Brasil passou por um processo de redemocratização com a promulgação de uma nova constituição, em 1988. Mesmo tendo sido uma das constituições mais avançadas do mundo em relação à garantia e defesa de Direitos Humanos fundamentais, poucas ações por parte do Estado foram feitas para reparar esse passado de violações de direitos. A única atitude de reparação mais reverberante tomada foram as tardias comissões da verdade, que apesar de tardias, criaram uma dimensão pública para as narrativas, vozes silenciadas no âmbito do Estado por décadas tiveram espaços públicos para oitivas. As comissões atuaram em âmbitos nacional, estadual e municipal e tinham por objetivo apurar graves violações de Direitos Humanos ocorridas entre 18 de setembro de 1946 e 5 de outubro de 1988. Após o fim de suas operações, as comissões da verdade indicaram uma série de posturas a serem tomadas a fim de reparar as vítimas de violações nesse período e de impedir que outras violações ocorressem. Apesar de ter sido criada pelo decreto $\mathrm{n}^{\circ}$. 7.671, em 15 de abril de 2014, a Comissão da Verdade de Barra Mansa foi esvaziada e, descontinuada, não realizou apurações e tampouco apresentou relatório.

\title{
5 Os dados empíricos
}

Para compreender o impacto da ausência de referências contemporâneas relativas ao histórico de violações de Direitos Humanos ocorridas em Barra Mansa, durante o regime de exceção brasileiro (1964-1985), foi realizada a aplicação de questionário em três escolas do 
município. Responderam ao questionário a totalidade de alunos de quatro turmas que estavam concluindo o terceiro ano do ensino médio, assim como, os alunos de duas turmas do último módulo do Ensino de Jovens e Adultos (EJA). A fim de compreender aspectos subjetivos acerca das representações sobre violações de Direitos Humanos e o município, foi realizado um grupo focal com sete pessoas ${ }^{15}$ das turmas do EJA. As escolas, objeto desse estudo, encontram-se a cerca de 1,5 km do "Arquivo", local onde as torturas eram praticadas, de acordo com os depoimentos de sobreviventes, durante as diligências realizadas no antigo BIB pela Comissão da Verdade de Volta Redonda - Dom Waldyr Calheiros realizadas. A escolha de turmas que estavam terminando o ensino médio objetivou a compreensão sobre como a temática acerca dos Direitos Humanos é inserida na vida escolar dos jovens ao longo dos ensinos fundamental e médio. E sobretudo, identificar se os estudantes tiveram contato com a temática a partir do histórico de seu próprio município, já que o mesmo foi cenário de graves violações de direitos durante a ditadura brasileira.

O questionário foi composto por 10 perguntas, sendo 9 fechadas e uma última pergunta aberta. Aplicado com o intuito de verificar o conhecimento dos estudantes sobre a memória da ditadura militar no município, o questionário também buscou compreender a opinião dos estudantes quanto aos Direitos Humanos.

Na última escola visitada, que é limítrofe ao local onde ocorriam as torturas, também foi aplicado um grupo focal para se obter uma percepção nuançada sobre a temática entre os alunos. Participaram deste grupo focal sete estudantes com faixa etária entre 20 a 43 anos, essa faixa etária explica-se, em função do grupo focal ter sido realizado com alunos do EJA.

\section{Apresentação e discussão dos resultados}

61. Sobre os resultados obtidos

A primeira escola visitada foi o Colégio Estadual Iracema Leite Nader, localizado no bairro Vila Nova à 1,5 km do "Arquivo". Nesta escola 56 alunos divididos em duas turmas responderam ao questionário. Nesta escola apenas 12 estudantes afirmaram não ter certeza do que são os Direitos Humanos. Ao serem perguntados se sabiam se o Estado (ou seus agentes) já havia praticado torturas, 53 entrevistados disseram que sim, e ao serem questionados se achavam que apenas militantes políticos foram presos, torturados e assassinados durante a ditadura, 46 alunos discordaram. Ao direcionar cada vez mais o questionário às questões que ajudariam a atingir o objetivo proposto nesse trabalho foi perguntado se eles sabiam que em

\footnotetext{
${ }^{15}$ Alunos que se voluntariaram a participar do grupo focal, sem prévia seleção pelos pesquisadores.
} 
Barra Mansa havia um local onde torturas eram praticadas durante a ditadura militar. Neste caso, 49 disseram que não tinham conhecimento, e dos 7 que afirmaram ter conhecimento, 4 disseram ter sabido através de parentes.

Você sabe o que são Direitos Humanos?

12

1

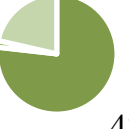

43

- SIM $\quad$ NÃO $\quad$ NÃO TENHO CERTEZA

Gráfico 1

Você acha que o Estado (governo) ou seus agentes já praticaram violações de Direitos Humanos?

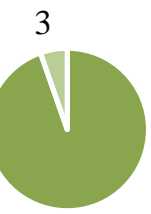

53

- SIM $\backsim$ NÃO

Gráfico 2

Você sabia que em Barra Mansa havia um local onde torturas eram praticadas durante $\mathrm{o}$ Regime Militar?

7

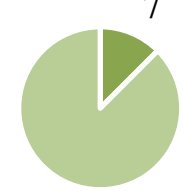

49

- SIM $\backsim$ NÃO

Gráfico 3 
A segunda escola visitada foi o Colégio Estadual Comendador Pereira Ignacio localizado no bairro Saudade, à 768,61 m do "Arquivo". Em um número menor do que a primeira escola visitada, aqui foram aplicados 30 questionários em duas turmas de concluintes do ensino médio. Nesta escola 7 estudantes afirmaram não ter certeza do que são os Direitos Humanos. Perguntados se sabiam que o Estado já havia praticado torturas, 29 entrevistados disseram que sim, e ao serem questionados se apenas militantes políticos foram presos, torturados e assassinados durante a ditadura, 25 alunos discordaram. Ao perguntar se eles sabiam que em Barra Mansa havia um local onde torturas foram praticadas durante a ditadura militar, apenas 6 entrevistados afirmaram ter conhecimento, Neste caso, 3 disseram que souberam deste fato através de pessoas próximas e conhecidos.

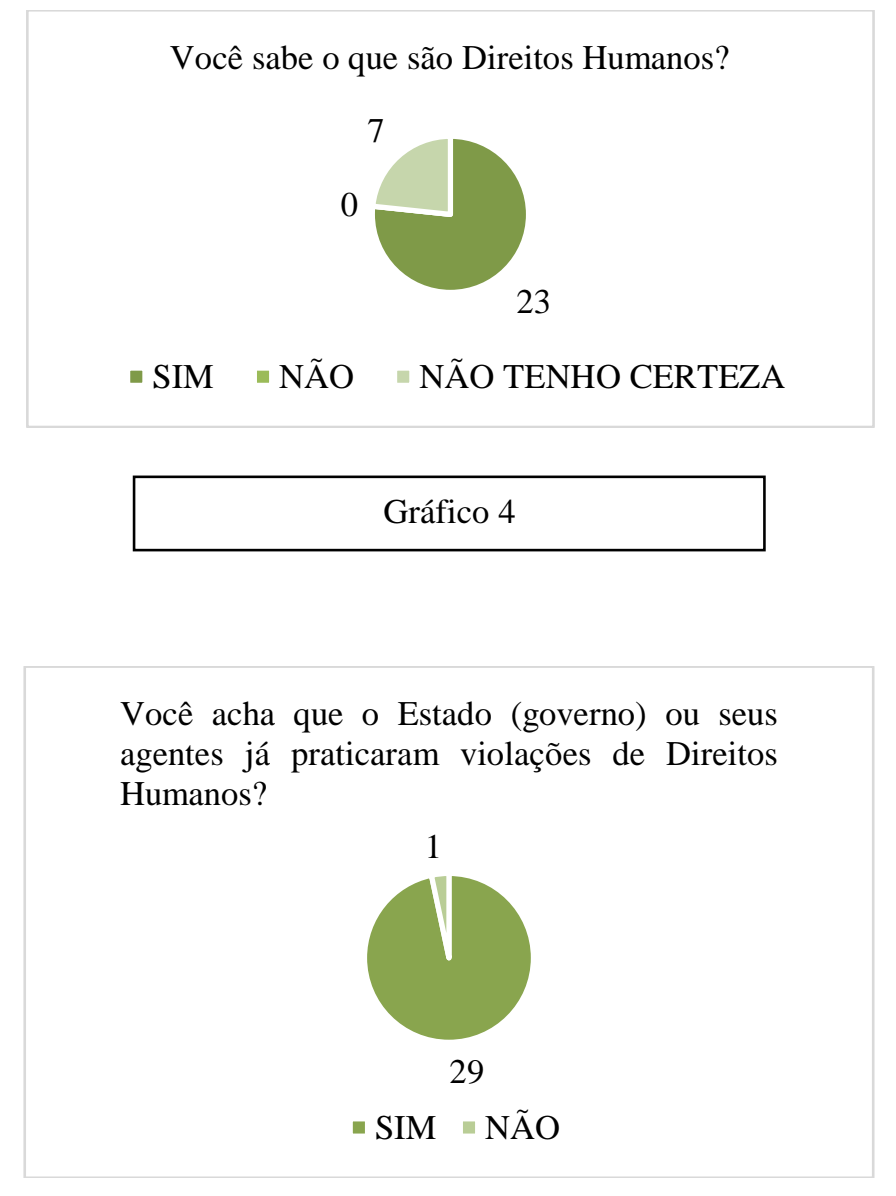

Gráfico 5 
Você sabia que em Barra Mansa havia um local onde torturas eram praticadas durante o Regime Militar?

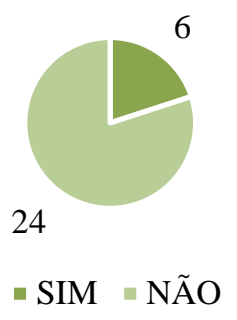

Gráfico 6

Por fim, a terceira escola visitada foi o CIEP 485 - Professor João Batista de Barros, localizado no bairro Bom Pastor, com uma distância de apenas 250 m do "Arquivo", onde 37 alunos do EJA divididos em duas turmas responderam ao questionário. Nesta escola 5 estudantes afirmaram não ter certeza do que são os Direitos Humanos, mas nenhum aluno afirmou não saber do que se trata. Ao serem perguntados se sabiam que o Estado já praticou torturas, 34 entrevistados disseram que sim, e ao serem questionados se apenas militantes políticos foram presos, torturados e assassinados durante a ditadura, 34 alunos também discordaram. Quando responderam se eles sabiam que em Barra Mansa havia um local onde torturas foram praticadas durante a Ditadura Militar, 28 disseram que não tinham conhecimento. Porém, dos 6 que afirmaram ter conhecimento, 5 afirmaram ter sabido através de parentes.

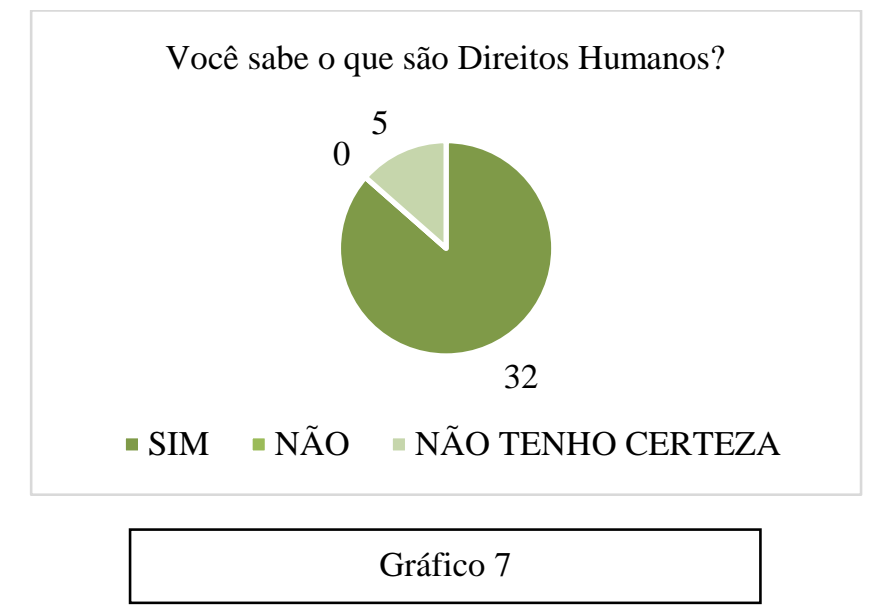


Você acha que o Estado (governo) ou seus agentes já praticaram violações de Direitos Humanos?

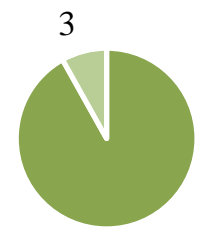

34

- SIM $=$ NÃO

\section{Gráfico 8}

Você sabia que em Barra Mansa havia um local onde torturas eram praticadas durante o Regime Militar?

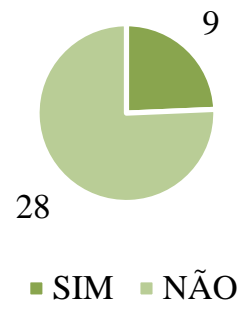

Gráfico 9

\subsection{Sobre o grupo focal}

$\mathrm{Na}$ última escola visitada realizou-se um grupo focal onde foi adotado um roteiro dividido em quatro partes. Em um primeiro momento foi perguntado aos participantes, para estimular o debate, o que o espaço do atual "Parque da Cidade" significava para eles. Os entrevistados disseram que o local hoje em dia não significa nada para eles, além de um local onde os homens se alistam para cumprir o serviço militar obrigatório ${ }^{16}$. Segundo um dos entrevistados lá não significa nada para ele, “até porque eles não oferecem nada, né?! Não tem como a gente ter alguma coisa lá dentro”.

Também foi abordado no grupo o tema dos Direitos Humanos, o que são? O que significam para eles? O que eles pensam sobre algumas falas, como: "Direitos Humanos só

\footnotetext{
${ }^{16}$ Até hoje o local abriga um Tiro de Guerra, onde os munícipes realizam o alistamento militar obrigatório ao completar os 18 anos de idade.
} 
defendem bandidos"? E "Direitos Humanos para humanos direitos"? Os participantes aqui apontaram os Direitos Humanos como algo universal e como "direito de fazer o que quiser, quando quiser, na hora que quiser" afirmou um participante. "Vestir o que quiser”, disse outro. “Lutar pelo que a gente quer”, disse o terceiro e, "ser o que você quiser ser”, afirmou o quarto participante. Os entrevistados mencionaram a perseguição aos defensores de Direitos Humanos, citando o caso da vereadora carioca Marielle Franco ${ }^{17}$ : "Só tirar o exemplo ai agora daquela mulher que mataram ela, que ela defendia lá, e mataram ela", afirmou um dos participantes.

Para relacionar o tema debatido, a saber Direitos Humanos, às perseguições, prisões arbitrárias e torturas durante a ditadura foi mostrado em um terceiro momento uma imagem do filme "Batismo de Sangue". Trata-se da cena em que um personagem sofre tortura no instrumento conhecido como 'pau-de-arara' e, em seguida, perguntamos aos entrevistados o que eles achavam daquela imagem. Neste momento começamos a abordadar a temática da ditadura no país e no município. Em conjunto eles disseram que dependendo do motivo pelo qual a pessoa está sendo torturada, a prática pode ser considerada legítima. Porém, alguns logo após essa manifestação mudaram o posicionamento. Assim sendo, obteve-se duas respostas distintas quando perguntado se eles concordam com a legitimação da prática da tortura por parte do Estado: "eu já não concordo não, mesmo se ele tiver feito uma coisa errada, não concordo com a violência, não é bem por ai”, afirmou um participante; e "Eu concordo, porque você tem uma filha lá de 4 anos, ai vem um camarada lá e 'estrupa' sua filha, e aí? Entra dentro da sua casa, mata seu filho, 'estrupa' sua filha e aí? Você vai dá beijinho nele?”, protestou em seguida, outro. Em contraponto a essa colocação, uma participante disse: "Tem relatos de pessoas que passaram por essa situação e não têm esse mesmo pensamento. Vi um caso de São Paulo, foi até um japonês, o cara passou por isso, mataram a família dele, depois ele foi lá e conversou com o cara de boa".

Observamos durante a realização do grupo focal certa legitimação da tortura por parte do Estado, quando praticada "em casos específicos". Assim, percebe-se que há necessidade de tratar a temática dos Direitos Humanos dentro das salas de aula. É importante ressaltar que as diretrizes curriculares nacionais do ensino médio deixam claro que esse tema deve ser trabalhado nas escolas, promovendo-o e considerando-o nas propostas pedagógicas de todas as unidades. Assim como a pluralidade das memórias sociais também deve ter espaço garantido na formação básica dos cidadãos.

17 Vereadora do Rio de Janeiro assassinada em 14 de março de 2018. Suas maiores bandeiras na política eram a defesa dos Direitos Humanos, dos LGBT's e dos moradores de favelas. 
Após esse debate foi perguntado aos estudantes o que eles sabiam sobre a ditadura brasileira e o que eles tinham estudado sobre esse período na escola. Em conjunto eles disseram que não conheciam o período a fundo e uma das participantes do grupo focal disse o que viram superficialmente: "A gente escutou falar de pessoas que procuram o corpo, buscam indenização do governo, mais nada não”, afirmou.

Em seguida, relatamos aos entrevistados alguns dos episódios de torturas ocorridas no antigo BIB, em Barra Mansa. Um dos estudantes, que no questionário informou que sabia que no local funcionou um centro de torturas, pode explicar melhor sobre como ele teve acesso aquela informação: "É o que eu sei, meus familiares sempre foi daqui mas me contavam as histórias, meu avô principalmente, que viveram nessa época, ele disse que ali foi a central de como se fosse a AMAN, só que em Barra Mansa, central do Brasil inteiro, só que ali servia como sede de tortura. É o que ele me falava” . Após essa explicação os alunos se mostraram perplexos ao saberem que o local conhecido como "Parque da Cidade" foi um centro de torturas. "Eu vejo ali com outros olhos, como um espaço divertido", afirmou um participante; "Uns anos atrás a gente ia lá, curtia, zuando, não sabia nada disso. Ninguém deve saber”, disse outro; "ia morrer sem saber", completou um terceiro.

\subsection{O ambiente escolar e o enquadramento da memória}

Desde a publicação de "A Reprodução", por Bourdieu e Passeron (1992) sabemos que o sistema de ensino, em certa medida, reproduz a cultura dominante e, assim, as relações de poder observadas na esfera social em que está inserido. Não sendo novidade, portanto, que as memórias daqueles que foram silenciados pela história, sobretudo através da violência, física e simbólica, praticada pelo Estado (ou em seu nome) tivessem pouca relevância nas atividades formativas, ou no ambiente escolar. Contudo, o caso do município de Barra Mansa merece destaque. Não só por ter sido este o único município a abrigar um IPM $^{18}$ (Inquérito Policial Militar) que condenou torturadores durante a ditadura civil-militar no Brasil (década de 1970), mas por tratar deste período da história do país, no ambiente escolar, sem fazer qualquer referência aos fatos ocorridos na localidade. Essa especificidade lança luz sobre o que Pollak (1989) chamou de enquadramento da memória. Porém, como dito acima, esse processo é arbitrário. Considerando o estudo de caso acima relatado, sabemos que houve, em algum momento da formação dos educandos, a presença das discussões sobre a ditadura brasileira. Porém parece não ter ocorrido, ao longo dessas discussões, correlação entre os fatos ocorridos

${ }^{18}$ IPM n $^{\circ} 17 / 72$. 
no município e as violações de Direitos Humanos praticadas no país ao longo deste período. $\mathrm{O}$ tema é estudado sem menções ao papel desempenhado pela violência de Estado na cidade de Barra Mansa, conforme mencionado nos depoimentos de estudantes que participaram do grupo focal: "Uns anos atrás a gente ia lá, curtia, zuando, não sabia nada disso. Ninguém deve saber", disse; "ia morrer sem saber", completou outro. Assim destacamos as evidências que corroboram nossa hipótese de trabalho inicial, o fato dessas escolas jamais terem abordado os casos de torturas e assassinatos ocorridos no município dentro das salas de aula. Pode-se afirmar que atualmente, o Estado, apesar dos negacionismos recentes, adota como parte da memória oficial a ocorrência de um passado marcado por violações de Direitos Humanos, sobretudo, durante o período entre 1964 e 1985. Porém, na localidade, os egressos da rede de ensino do município, pelo menos naquelas escolas em que os alunos foram ouvidos para execução deste trabalho, não sabem que casos de tortura praticados por agentes do Estado ocorreram tão próximo, em sua própria cidade. E embora esse seja o caso concreto de pelo menos três unidades de ensino médio do município, acreditamos que a situação estende-se às demais. Os egressos do ensino médio do município que ingressam no Instituto de Ciências Humanas e Sociais da Universidade Federal Fluminense, revelam igual perplexidade ao tomarem conhecimento acerca das violações ocorridas no antigo BIB.

Percebe-se no caso de Barra Mansa que o processo de enquadramento da memória beneficiou aqueles que praticaram torturas, não expondo o passado de violações de Direitos Humanos ocorridas no município. Assim sendo, o processo de enquadramento silencia vozes e coloca no subterrâneo da história aqueles que tiveram seus direitos violados.

Uma explicação para essa arbitrariedade encontrada no processo de enquadramento da memória está dentro do conceito de "entulho autoritário", apresentado por Edson Teles (2009). Podemos afirmar que esse "entulho autoritário" também resulta no que Pollak (1989) chamou de "memória subterrânea". No caso que analisamos observa-se que egressos e alunos que estão terminando o ensino médio, no município, compreendem que houve um passado (e presente) de violações de Direitos Humanos no Brasil praticadas pelo Estado (ou em seu nome). Porém, no que diz respeito ao período da ditadura brasileira, para esses concluintes ou egressos, tratarse-ia de algo distante da localidade. Fatos que só teriam ocorrido nas capitais do país, ou em locais de resistência armada, como no Araguaia, por exemplo.

Contudo, destaca-se que apesar de subterrânea a memória dos silenciados continuou viva, latente. $\mathrm{O}$ fato desta memória ter passado de geração em geração nas famílias que sofreram 
as violações de direitos, ou pelos próprios violados, permitiu sua sobrevivência em certos círculos sociais.

Para além disso, com as ações das comissões da verdade, observa-se uma tentativa de trazer à tona as vozes silenciadas pela história, através da história oral das vítimas e seus familiares. Como abordado por Pollak (1989), esperava-se que esse passado submergido pudesse vir à lume fomentando novas narrativas e devolvendo ao processo educacional seu caráter plural. Ao mostrar que na região casos brutais de violações de Direitos Humanos ocorreram, a 'batalha pela memória' ganharia as vozes que foram interrompidas. Porém, a pesquisa de campo nos apresentou uma realidade bem diferente.

A implementação de uma política pública de memória de caráter nacional, ainda que tardia e insuficiente, reverberou em alguns estados e cidades do país. Neste âmbito as comissões da verdade visavam permitir uma disputa mais equânime no campo das narrativas sobre a verdade acerca das violações e garantir, dessa forma, justiça e reparação. Essa disputa de narrativas, enseja uma disputa pela memória e tem o potencial de alterar a ordem entre a memória oficial e a subterrânea, ressignificando a história e dando oportunidade de oitiva às vozes silenciadas por tanto tempo. Mas percebemos, com o trabalho de campo, que os relatórios das comissões da verdade não foram aproveitados nas escolas ou em seus conteúdos programáticos de ensino. Pelo menos é o que parece ter ocorrido com o documento de 589 páginas, chamado Relatório Final ${ }^{19}$ da Comissão Municipal da Verdade de Volta Redonda Dom Waldyr Calheiros. Esse relatório foi consubstanciado por 89 depoimentos prestados à Comissão.

Como mencionado acima, é preciso destacar que essa política foi realizada tardiamente, 27 anos após o fim da ditadura militar. Em um segundo momento pode-se citar a descontinuidade da Comissão da Verdade em Barra Mansa, cabendo à Comissão de Volta Redonda desenvolver alguns dos trabalhos que deveriam ter sido desempenhados pelo município vizinho, ou com seu apoio. Também é preciso destacar a inexistência de grupos de apoio a torturados e seus familiares na região Sul Fluminense, a exemplo do grupo "Tortura Nunca Mais" na capital do estado. Fato que pode ter contribuído para que diversas vozes, sem lugar de oitiva, permanecessem silenciadas, habitando o ‘subterrâneo' da nossa história.

\footnotetext{
${ }^{19}$ Relatório Final disponível em: http://cemesf.vr.uff.br/textos/relatorio-final-da-comissao-municipal-da-verdadedom-waldyr-calheiros-cmv-vr/
} 


\section{Considerações finais}

Considerando os dados acima apresentados, pode-se chegar à conclusão de que os egressos da rede de ensino municipal e estadual do município de Barra Mansa desconhecem o fato de que a cidade foi palco de severas violações de Direitos Humanos. Encontramos aqui a ocorrência do processo de enquadramento da memória no município, enquadramento que ocorre também através da própria rede de ensino local, já que os alunos do último ano do ensino médio desconhecem parte importante da história da cidade. Os poucos que relevaram conhecêla, tiveram acesso às informações através de parentes ou amigos, nunca por meio da rede de ensino.

Aqui vemos que após o período da ditadura brasileira (1964-1985) foi forjada a memória oficial através do processo de enquadramento. Esse processo impediu que em Barra Mansa as memórias soterradas pelo silêncio imposto por uma redemocratização pactuada pudessem auxiliar na ruptura da fronteira que separa essas vozes (silenciadas) da memória oficial. Além disso, tentativas promovidas pelo governo federal para o rompimento dessa fronteira, com políticas públicas já tardias como as Comissões da Verdade, se mostraram por enquanto, insuficientes. Já se passaram quase quatro anos do encerramento dos trabalhos da Comissão Municipal da Verdade de Volta Redonda - Dom Waldyr Calheiros, até o fim do ano de 2019 os alunos concluintes do ensino médio de três escolas do município de Barra Mansa ainda desconheciam as violações de Direitos Humanos praticadas naquela localidade durante a ditadura civil-militar brasileira. O que parece demonstrar a insuficiência dessa política pública em garantir a pluralidade de vozes, a justiça e a reparação das vítimas da violência de Estado. Muito ainda precisará ser feito para trazer esse passado à tona sob diferente perspectiva. Destaca-se ainda o fato de que o município de Barra Mansa não deu continuidade à sua própria Comissão Municipal da Verdade. Houve um processo inicial de formação desta Comissão, porém sem continuidade, cabendo à Comissão de Volta Redonda realizar o levantamento de fatos da região como um todo. Para além disso, ressaltamos que não existem políticas públicas municipais consolidadas. Também parece inexistir esforços para a abordagem do tema dentro das salas de aula, já que os alunos, egressos de ensino fundamental ofertado pela rede municipal de ensino e formandos no ensino médio, não se depararam (durante sua formação escolar) com narrativas sobre os episódios de tortura e morte em Barra Mansa durante o regime militar.

Também é importante destacar a ausência de debates sobre Direitos Humanos nas salas de aulas, percebida através da realização do grupo focal. O momento em que um participante 
concorda com a legitimação da tortura por parte do Estado, 'em casos especificos', é o retrato da barbárie. Vê-se claramente a necessidade de abordar a relevância dos Direitos Humanos no ambiente escolar, tal como preconizam as diretrizes curriculares nacionais da educação básica. Por tudo isso, podemos parafrasear Chico Buarque: a "página infeliz da nossa história", chamada de ditadura civil-militar, não é lida tampouco retratada dentro do ambiente escolar do município. Assim, a página não lida transforma-se em uma "passagem desbotada da memória de nossas novas gerações". E tem resultado num presente negacionista acerca desses episódios históricos (suficientemente documentados), saudosista de um passado autoritário e obscuro e, finalmente, testemunha de um presente vergonhosamente violento.

\section{Referências}

ARENDT, Hannah. Entre o passado e o futuro. São Paulo: Editora Perspectiva, 1988.

BEDÊ, E. D. A. T. Relatório Final. Comissão Municipal da Verdade Dom Waldyr Calheiros. Volta Redonda, p. 589. 2015.

BOURDIEU, Pierre; PASSERON, Jean-Claude. A Reprodução, elementos para uma teoria do sistema de ensino. $3^{\circ}$ Edição. Rio de Janeiro: Editora Francisco Alves, 1992.

CARVAlHO, J. M. Cidadania no Brasil. O longo Caminho. $3^{\text {a }}$ ed. Rio de Janeiro: Civilização Brasileira, 2002.

CENTRO DE MEMÓRIA DO SUL FLUMINENSE. Síntese do Processo Criminal a Que

Responde o Ten Cel Gladstone Pernasseti Teixeira. Disponível em: < http://cemesf.vr.uff.br/textos/sintese-processo-criminal-que-responde-o-ten-cel-gladstonepernasseti-teixeira/ > . Acesso em: 12/01/2020

COUTO, A. L. F. Do Império à República: a vida política no município de Barra Mansa. Tese (Doutorado em História, Política e Bens Culturais) - FGV - Fundação Getúlio Vargas, Rio de Janeiro, 2016.

DECLARAÇÃO UNIVERSAL DOS DIREITOS HUMANOS. Assembleia Geral das Nações Unidas em Paris. 10 dez. 1948. Disponível em: <https://nacoesunidas.org/wpcontent/uploads/2018/10/DUDH.pdf> . Acesso em: 15 nov. 2019.

HALBWACHS, M. A Memória Coletiva. Paris: Editora Albin Michel, 1990.

MARTINS, R. B. A Transferência Da Corte Portuguesa Para O Brasil: Impactos Sobre Minas Gerais in , Anais do XIII Seminário sobre a Economia Mineira [Proceedings of the 13th Seminar on the Economy of Minas Gerais], Cedeplar, Universidade Federal de Minas Gerais, 2008. 
MINISTÉRIO DA EDUCAÇÃO. Atualiza as Diretrizes Curriculares Nacionais para o Ensino Médio. Resolução no . 3, de 21 de novembro de 2018. Diário Oficial da União, Brasília, 22 nov. 2018, Seção 1, p. 21

POLLAK, M. Memória, Esquecimento, Silêncio. In: Estudos Históricos. Rio de Janeiro, v. 2, n. 3, p. 3-15, 1989.

SECCHI, L. Políticas Públicas: conceitos, esquemas de análise, casos práticos. $2^{\circ}$ Ed. São Paulo: Cengage Learning, 2014.

SERBIN, K. P. Diálogos na Sombra: Bispos e Militares, Tortura e Justiça Social na Ditadura. Tradução de Carlos Eduardo Lins Silva. São Paulo: Companhia das Letras, 2001.

TELES, E. Políticas do silêncio: a memória no Brasil pós-ditadura. Disponível em: http://www.academia.edu/640382/Pol\%C3\%ADticas_do_sil\%C3\%AAncio_a_mem\%C3\%B3 ria_no_Brasil_p\%C3\%B3s-ditadura, 2009.

Recebido em 30 de maio de 2021. Aceito em 04 de junho de 2021. 